\title{
ハトの鏡像逆転効果における刺激の大ささの役割
}

\author{
慶応義塾大学渡辺茂
}

\section{Size of discriminanda did not change mirror image interocular reversal in the pigeon}

\author{
Watanabe, S. \\ Department of Psychology \\ Keio University, Tokyo
}

\begin{abstract}
Pigeons were monocularly trained on mirror image discrimination using three different sizes of stimuli. The largest shape was $17.5^{\circ} \times 11.5^{\circ}$ and the smallest $3.3^{\circ} \times 3.3^{\circ}$. When the birds were tested with the untrained eye, paradoxical transfer was observed, i.e., $\mathrm{S}^{\triangle}$ was prefered with the untrained eye.

Contrary to the previous results with goldfish by other researchers, shift from paradoxical to veridical transfer depending on the size of discriminanda did not occur. The role of the tecto-fugal visual pathway in the paradoxical transfer was briefly discussed.
\end{abstract}

Key words: Interocular transfer, Mirror image, Pigeon, Stimulus size.

鏡像関係にある刺激の弁別を単眼で訓練すると, 非訓練眼使用時には $\mathrm{S}^{-}$亿対する選好が生ずる 事が，八ト(Mello，1966；Corballis \& Beale, 1967 ; Watanabe, 1979 ), 視神 経交叉切断のサル (Nohle，1968), キンギョ ( Ingle，1967)で知られている。

この現象は刺激の形には依然せず，視覚刺激の 運動方向の弁別においても認められるが（Me 11o， 1968 ), 刺激の大ささは重要な要因とされてい る。Ingle (1967；1968) は, キンギョの 回避条件ゔけにおいて, 視角が $15^{\circ}, 22^{\circ}$ の刺 激では鏡像逆転が生ずるが， $8^{\circ} \sim 10^{\circ}$ の大をさ では正常を両眼間転移が認められる事走報告した。 その後, Campbe11（1971）は，乙れを追試 確認し, 上下鏡像刺激の場合には刺激の大をさに 関らず正常䎐移が認められる事も示した。

Ingle 忙視覚系に刺激の形そのものを分析す
る形態分析過程と，体軸の前後方向を基準とした 刺激の方向を分析する方向性分析過程を想定し， 鏡像逆転効果は後者に上って生ずるとした。そし て，大をな刺激は方向性分析過程索活性化するの に対し，小さな刺激壮形態分析過程を活性化する としたが，ての仮説についての上り実証的な研究 は行われていない。

キンギョ以外では, Starr (1971)が視神経 交叉切断のサルに和いて刺激の大をさに依存した 鏡像逆転効果を報告しているが，Lehman(1973） は乙れを確認しておらず，刺激の大をさと鏡像逆 転効果の関係はキンギョ以外では充分に検討され ていない。

本実験の目的は鏡像逆転効果が明白に認められ るハトにおいて, Campbe11, Ingleが用いた ものと類似した刺激を使って刺激の大をさの持つ 効果を検討しようとするものである。 
方

法

被 験 体

デンショバト（Columba liva）4 個体を用 いた。各個体とも実験期間中は 80 パーセントの 体重統制下におかれた。

装置

ハト用オペラント箱 $(30 \times 30 \times 30 \mathrm{~cm})$ が用 らられた。前面パネルには床から $17 \mathrm{~cm}$ の所に透 明ガラスのスクリーン $(6.5 \times 9 \mathrm{~cm})$ があり, 被 験体はこのスクリーンを介してテレビ(ビクター CX 64 ）のブラウン管を見る事がでをる。刺激 はこのブラウン管に表示される。スクリーンには マイクロスイッチが付いており，つつを反応が測 定でをる。スクリーンの下にはフィーダの開口 部があり，強化として麻の実の入ったフィーダ を 4 秒間呈示した。実験制御はマイクロコンピュー 夕(Apple II) K上って行った。

刺激

刺激の形と大ささは図 1 亿示されている。視角 をHodos ら（1976）飞上るキイから角膜まで の距離 $51.5 \mathrm{~mm}$, Marshal1ら (1973) K上 る角膜から結節点までの距離 $3.46 \mathrm{~mm}$ ，及びスク リーンからブラウン管までの距離 $15 \mathrm{~mm}$ を使って 算出すると, 刺激Lの縦・横は $17.2^{\circ}$ と $11.5^{\circ}$, 刺激 $\mathrm{M}$ は $5.7^{\circ}$ と $4.9^{\circ}$, 刺激 $\mathrm{S}$ は $3.3^{\circ}$ と $3.3^{\circ}$ であった。各刺激は暗いブラウン管上に白色表示 され，明るさは約 $221 \mathrm{x}$ であった。

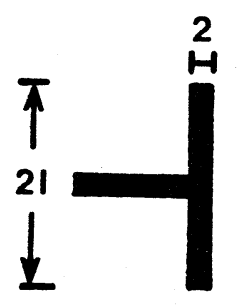

$k-14 \rightarrow-1$

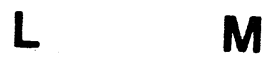

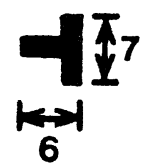

M

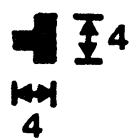

S
図 1 訓練に用いられた刺激。(単位: $\mathrm{mm}$ )いず れるブラウン管上に白色で表示される。 刺激の視角は本文中に記述されている。
手続

各個体は自動反応形成の手続に上りスクリーン に対するつつを反応を形成した後，刺激 $\mathrm{L}, \mathrm{M}$ と その鏡像 (合計 4 刺激 ) 飞対するVI2 0" の訓練 を $2 \sim 4$ 日間受ける。その後，塩化ビニル製の眼 筒を固定し, 両眼, 左右各単眼条件で上記 4 刺激 に対するVI 20 をを 2 4 日間受ける。

その後，単眼弁別訓練に入る。訓練には上記 4 刺激を用いてmult VI2 5" - EXT-VI2 5"一 $\mathrm{EXT}$ で行われ，左向をに凸部のある刺激が呈示

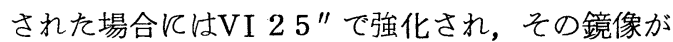
呈示されている時の反応は消去される。1セッシ ョンには 4 刺激が 10 回ずつランダムに呈示され, 1 回の呈示は 25 秒で呈示と呈示の間には 5 秒間 の暗間隔が挿入された。

ての訓練を 40 セッション行った後, 非訓練眼 でのテストを行う。テスト時には訓練時と同じ上 うに刺激が呈示されるが，強化は全く与えられな n。

その後, 刺激 $\mathrm{S}$ とその鏡像の弁別訓練を上記と 同じ訓練眼で行う。訓練はmult VI $25 "$ "EXT で, $\mathrm{S}^{\mathrm{D}}, \mathrm{S}^{\Delta}$ が 20 回ずつゲラマン系列飞従っ て呈示される。1 回の呈示は 25 秒で呈示と呈示 の間には 5 秒間の暗間隔がおかれた。

この訓練を 20 セッション行った時に非訓練眼 でのテストを行う。テストでは訓練と同じように 刺激が呈示されるが，強化は与えられない。

\section{結果}

図 2 亿最初の 40 セッションの訓練中の正反応 率の推移を示す。D 31 以外の個体では刺激 L K 対する弁別の方が速か儿形成されており，F 31 ， F 34 では訓練終了時においても刺激M飞対する 弁別は刺激しに対するもの上り劣っている。乙れ らの事は，大をな刺激の方がハトにとって弁別し やすかった事を示す。なお反応数については刺激 の大小に上る差は見られなかった。

刺激 $\mathrm{S}$ を用いた訓練では，各個体とも訓練初期 


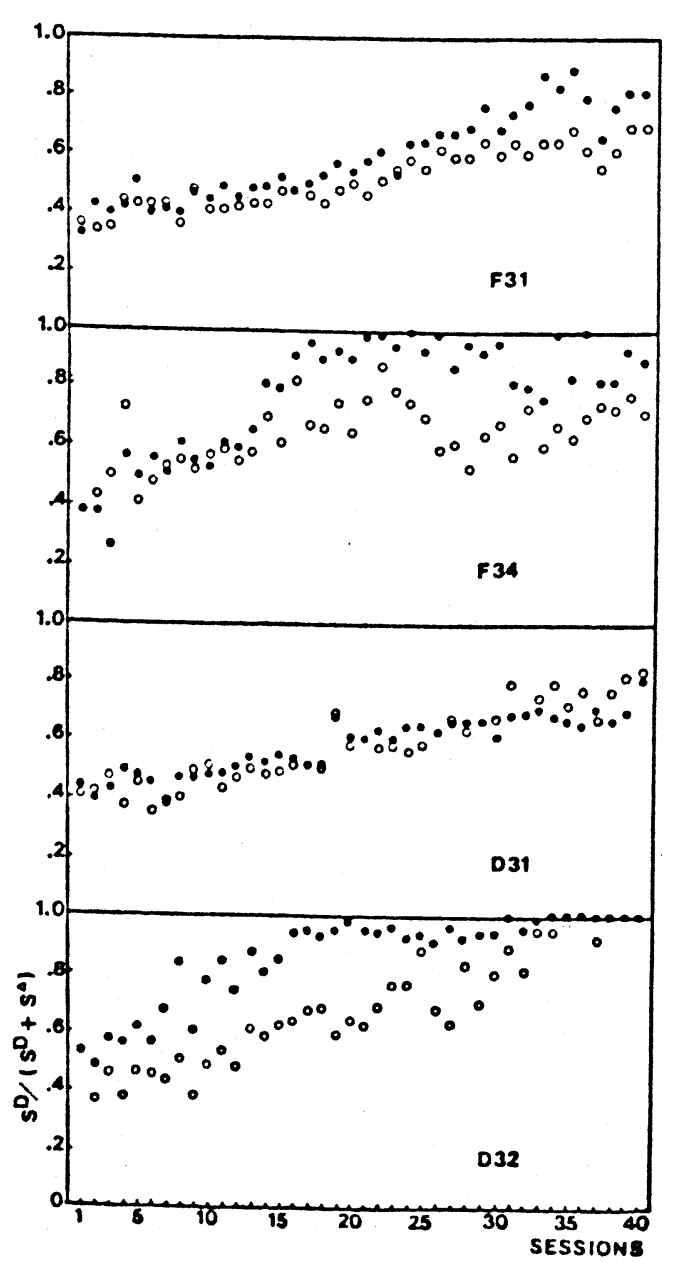

図240 セッションの訓練中の正反応率。 黒丸は刺激 L。白丸は刺激 $\mathrm{M}$ での成績を 示す。

は 60 パーセント程度の正反応率であった。この 事は, ある図形での鏡像弁別が同じ図形で大をさ の異なる刺激の鏡像弁別に良く転移しなかった事 を示す。なお，D３２亿秃ては訓練終了時にお らて正反応率は 70 パーセントに達さなかった。 転移テストの結果は図 3 亿示される。刺激 $\mathrm{M}$, $\mathrm{S}$ において非訓練眼での正反応率が 40 パーセン 卜をこえる個体が一例ずつあるが，いずれの刺激 におらてる非訓練眼では $\mathrm{S}^{\triangle}$ に対する選好が認め られ，刺激の大をさに依存して，逆転性転移から 正常な転移に移行する現象は見られなかった。な お，刺激 L と M ではMの方が転移時正反応率が高

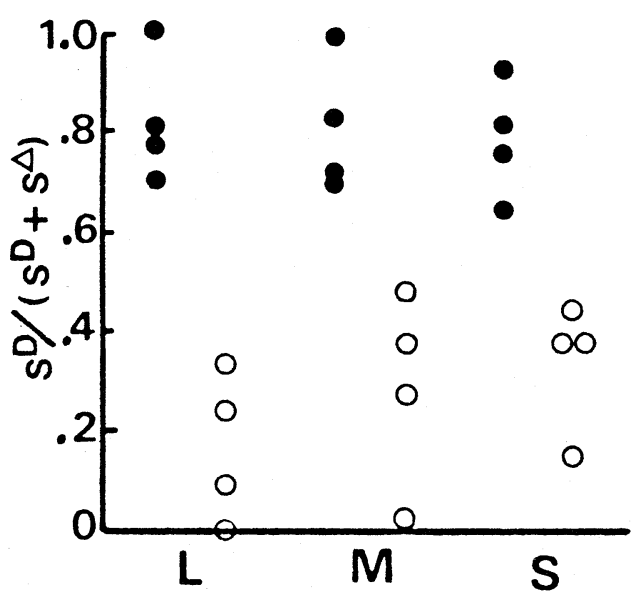

図 3 原訓練最終セッションと移転テストで の正反応率。黒丸は原訓練，白丸は移転 テストの結果を示す。

くなる傾向が見られた。

一方，すべてのデータについて訓練最終セッシ ョンの正反応率と転移テストの正反応率の相関係 数を求めると一.79 であった。乙の事は非訓練 眼での弁別行動が刺激の大ささではなく訓練眼で の弁別の程度に関係していた事を示唆する。

\section{考}

察

本実験はハトにおける鏡像逆転効果が刺激の大 ささに依存しない事を明瞭に示している。視角の 算出にはHodos ら（1976）のデータを用いた が，スクリーンから角膜充での距離をハトの角膜 からクチバシ先端までの長さ $(35 \mathrm{~mm}$ ) として計 算しても，刺激 $\mathrm{S}$ の縦横は $4.3^{\circ}$ と $4.3^{\circ}$, Mでは $7.5^{\circ}$ と $6.4^{\circ}$, Lでは $2.1^{\circ}$ と $15^{\circ}$ になり, Ingle や Campbe 11 がキンギョで認めたよう な視角 $10^{\circ}$ 以下では正常な転移が見られるとい ら現象はハトでは認められない。

Ingle らの主張する形態分析過程と方向性分 析過程は，八トの視覚系におらては大雑把には夫 夫thalamo-fugal 系とtecto-fugal 系飞 対応すると考えられる。Tha lamo-fugal系の 終末であるWuls t には両眼性ニューロンのある 
事が確認されており（Hunt＆Webster, 1972 ; Pereŝi ć et al, 1971 ), 両眼 間転移の一つの基礎とも考えられる。しかしなが ら, Wuls t 両側性破壊は両眼間転移を消失せし めず( Francesconi et al，1982), 又, 視交叉上交連切断は両眼間転移を消失せしめるも のの，視床から対側Wu l s t への径路がある視交 又上交連背部に限局した切断は両眼間転移を消 失せしめないという知見もある(渡辺, 1983 )。 視交叉上交連腹部はtectoーfugal 系の径路と なっており（Streit et al，1980：Hunt \& Künzle:, 1976 ), 乙れらの事はハトの両 眼間転移が主として tecto-fugal 采に依って らる可能性を示唆する。その上うな場合には，八 トにおいて一貫して鏡像逆転効果が生ずるかも知 れない。いずれにしても, 記憶の両半球間転移や 鏡像逆転効果の神経機構については, なお今後の 研究が必要である。

\section{要旨}

3 種類の異なる大ささの刺激を用いてハトに鏡 像弁別を単眼で訓練した。最大の刺激の視角は

$17.5^{\circ} \times 11.5^{\circ}$ であり, 最小のものは $3.5^{\circ}$ $\times 3.3^{\circ}$ であった。非訓練眼でテストを行うと各 個体とも $\mathrm{S}^{\Delta}$ 亿対する選好, 即ち鏡像逆転効果が 認められた。

従って, ハトにおらては, キンギョにつんて報 告されている上らな刺激の大ささに依存した逆転 的転移から正常な転移の变化は認められなかった。 なお，鏡像逆転効果におけるtecto-fuga 1 系 の役割が論じられた。

\section{REFERENCES}

Campbell, A. 1971 Interocular transfer of mirror images by goldfish. Brain Res., 33, 486-490.

Corballis, M.C., \& Beale, I.L. 1967 Interocular transfer following simultaneous discrimination of mirror image stimuli. Psychon. Sci.,
$9,605-606$.

Francesconi, W., Fogassi, L., \& Musumei, D. 1982 Interocular transfer of visual discrimination in Wulst ablated pigeons. Behav. Brain Res., 5, 399-406.

Hodos, W., Leibowitz, R.W., \& Bonbright, J.C. 1976 Nearfield visual acuity of pigeons: Effects of head location and stimulus luminance. J. exp. Anal. Behav., 25, 129-141.

Hunt, S.P., \& Künzle, H. 1976 Observations on the projections and intrinsic organization of the pigeon optic tectum: An autoradiographic study based on anterograde and retrograde, axonal and dendritic flow. J.com. Neur., $170,153-172$.

Hunt, S.T., \& Webster, K.E. 1972 Thalamo-hyperstriate inter-relations in the pigeons. Brain Res., 44, 647-651.

Ingle, D. 1967 Two visual mechanisms underlying the behavior of fish. Psychol. Forsch., 31, 44-51.

Ingle, D. 1968 Spatial dimensions of vision in fish. In D. Ingle, (Ed.) The central nervous system and fish behavior, Chicago Univ. Press.

Lehman, R.A.W. 1973 Interocular reversal of preference for lateral mirror image shapes by the monkey with sectioned optic chiasm. Brain Res., 64, 419-424.

Marshall, J., Mellerio, J., \& Palmer, D.A. 1973 A schematic eye for the pigeon. Vision Res., $18,2449-2453$.

Mello, N. 1966 Interocular generalization: A study of mirror image reversal following monocular discrimination training in the pigeon. J. exp. Anal. Behav., 9, 11-16.

Mello, N. 1968 Interhemispheric transfer of a discrimination of moving patterns in pigeons. Brain Res., 7, 390-398.

Noble, J. 1968 Paradoxical interocular transfer of mirror image discriminations in the optic chiasm sectioned monkey. Brain Res., 10, 127-151.

Peressić, M., Mihailovic, J., \& Cuénod, M. 1971 Electrophysiology of contralateral and ipsilateral visual projections to the Wulst in 
pigeon (Columba livia). Int. J. Neurosci., 2, 7-14.

Starr, B.S. 1971 Veridical and paradoxical interocular transfer of left/right mirror image discriminations. Brain Res., 31, 377.

Streit, P., Stella, M., \& Cuénod, M. 1980 Transneuronal labelling in the pigeon visual system. Neurosci., 5, 763-775.
Watanabe, S. 1979 Mirror image discrimination with each eye in pigeons. Physiol. \& Behav., $22,331-337$.

渡辺 茂 1983 ハトにおける記憶の両半球間 転移に及ぼす視交叉上交連破壊の効果 (要旨) 基礎心理学研究 (印刷中)

- 1983 年 11 月 22 日受稿; 1984 年 1 月 22 日受理一

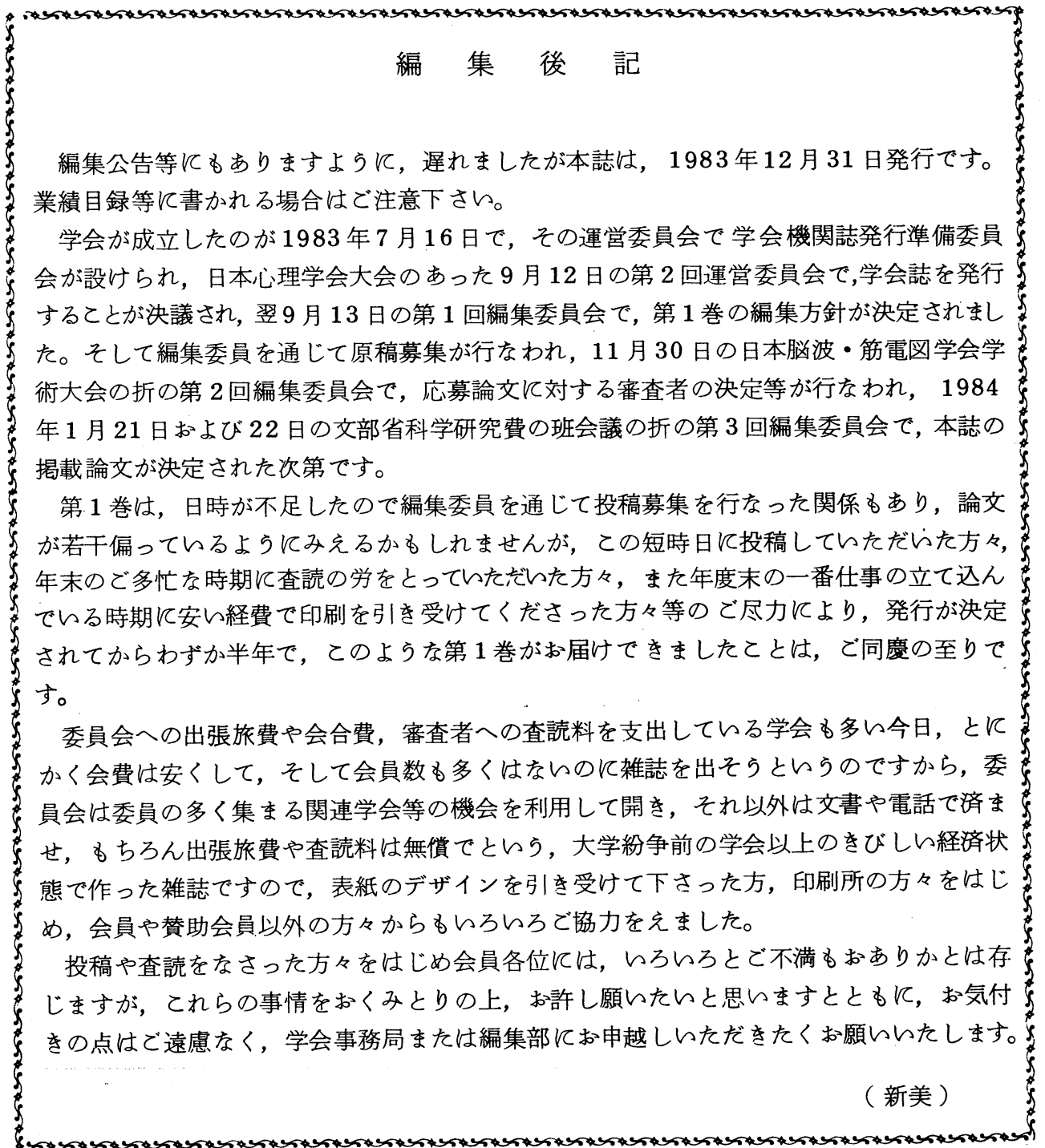

